\title{
Natronoarchaeum mannanilyticum gen. nov., sp. nov., an aerobic, extremely halophilic archaeon isolated from commercial salt
}

Correspondence

Yasuhiro Shimane yshimane@jamstec.go.jp

\author{
Yasuhiro Shimane, ${ }^{1,2,3}$ Yuji Hatada, ${ }^{1}$ Hiroaki Minegishi, ${ }^{2,3}$ Toru Mizuki, ${ }^{2,3}$ \\ Akinobu Echigo, ${ }^{2,3}$ Masayuki Miyazaki, ${ }_{1}^{1}$ Yukari Ohta, ${ }^{1}$ Ron Usami, ${ }^{2,3}$ \\ William D. Grant ${ }^{4}$ and Koki Horikoshi, ${ }^{1,2}$ \\ 1Japan Agency for Marine-Earth Science and Technology, 2-15 Natsushima-cho, Yokosuka-shi, \\ Kanagawa 237-0061, Japan \\ ${ }^{2}$ Toyo University, 2100 Kujirai, Kawagoe-shi, Saitama 350-8585, Japan \\ ${ }^{3}$ Bio-Nano Electronics Research Center, Toyo University, 2100 Kujirai, Kawagoe-shi, \\ Saitama 350-8585, Japan \\ ${ }^{4}$ Department of Infection, Immunity and Inflammation, University of Leicester, Room 144, \\ Maurice Shock Medical Sciences Building, Leicester, UK
}

\begin{abstract}
Strain YSM $-123^{\top}$ was isolated from commercial salt made from Japanese seawater in Niigata prefecture. Optimal $\mathrm{NaCl}$ and $\mathrm{Mg}^{2+}$ concentrations for growth were $4.0-4.5 \mathrm{M}$ and $5 \mathrm{mM}$, respectively. The isolate was a mesophilic and slightly alkaliphilic haloarchaeon, whose optimal growth temperature and $\mathrm{pH}$ were $37^{\circ} \mathrm{C}$ and $\mathrm{pH}$ 8.0-9.0. Phylogenetic analysis based on $16 \mathrm{~S}$ rRNA gene sequence analysis suggested that strain $\mathrm{YSM}-123^{\top}$ is a member of the phylogenetic group defined by the family Halobacteriaceae, but there were low similarities to type strains of other genera of this family $(\leqslant 90 \%)$; for example, Halococcus (similarity $<89 \%)$, Halostagnicola $(<89 \%)$, Natronolimnobius ( $<89 \%)$, Halobiforma $(<90 \%)$, Haloterrigena $(<90 \%)$, Halovivax $(<90 \%)$, Natrialba $(<90 \%)$, Natronobacterium $(<90 \%)$ and Natronococcus $(<90 \%)$. The $\mathrm{G}+\mathrm{C}$ content of the DNA was $63 \mathrm{~mol} \%$. Polar lipid analysis revealed the presence of phosphatidylglycerol, phosphatidylglycerophosphate methyl ester, disulfated diglycosyl diether and an unknown glycolipid. On the basis of the data presented, we propose that strain YSM-123 should be placed in a new genus and species, Natronoarchaeum mannanilyticum gen. nov., sp. nov. The type strain of Natronoarchaeum mannanilyticum is strain YSM $-123^{\top}$ (=JCM $16328^{\top}$ $=$ CECT $7565^{\top}$ ).
\end{abstract}

The extremely halophilic, aerobic archaea that require least $1.5 \mathrm{M} \mathrm{NaCl}$ for growth are placed in the family Halobacteriaceae, order Halobacteriales, class 'Haloarchaea' (Grant et al., 2001). The current classification of this family is based mainly on three taxonomic characters: 16S rRNA gene sequence, polar lipid composition and DNA-DNA hybridization (Oren et al., 1997; Grant et al., 2001). At the time of writing, the aerobic, extremely halophilic archaea are classified within 27 different genera. The type species of these genera are Halobacterium salinarum (Elazari-Volcani, 1957), Halococcus morrhuae (Kocur \& Hodgkiss, 1973), Natronobacterium

The GenBank/EMBL/DDBJ accession numbers for the 16S rRNA gene sequences of strain $\mathrm{YSM}-123^{\top}$ are AB501361 (rrnA) and AB501360 ( $r r n B)$.

Results of TLC of polar lipids of strain $\mathrm{YSM}-123^{\top}$ and related haloarchaea are available as supplementary material with the online version of this paper. gregoryi (Tindall et al., 1984), Haloarcula vallismortis (Torreblanca et al., 1986), Haloferax volcanii (Torreblanca et al., 1986), Natronococcus occultus (Tindall et al., 1984), Halobaculum gomorrense (Oren et al., 1995), Halorubrum saccharovorum (McGenity \& Grant, 1995), Natrialba asiatica (Kamekura \& Dyall-Smith, 1995), Natronomonas pharaonis (Kamekura et al., 1997), Halogeometricum borinquense (Montalvo-Rodríguez et al., 1998), Natrinema pellirubrum (McGenity et al., 1998), Haloterrigena turkmenica (Ventosa et al., 1999), Natronorubrum bangense (Xu et al., 1999), Halorhabdus utahensis (Wainø et al., 2000), Halobiforma haloterrestris (Hezayen et al., 2002), Halomicrobium mukohataei (Oren et al., 2002), Halosimplex carlsbadense (Vreeland et al., 2002), Halalkalicoccus tibetensis (Xue et al., 2005), Natronolimnobius baerhuensis (Itoh et al., 2005), Halovivax asiaticus (Castillo et al., 2006a), Halostagnicola larsenii (Castillo et al., 2006b), Haladaptatus paucihalophilus (Savage et al., 2007), Halopiger xanaduensis (Gutiérrez et al., 2007), 
Haloplanus natans (Bardavid et al., 2007), Haloquadratum walsbyi (Burns et al., 2007) and Halosarcina pallida (Savage et al., 2008).

Most salt that is sold in Japan is made from seawater concentrated in salterns and then evaporated by heating. In this paper, we describe a halophilic archaeal strain, YSM$123^{\mathrm{T}}$, which was isolated from commercial salt made by the heating process in Niigata, Japan. Strain YSM- $123^{\mathrm{T}}$ was isolated from a salt sample that was produced and sold in Japan using medium $168 \mathrm{M}$ [containing $\left(\mathrm{l}^{-1}\right): 200 \mathrm{~g} \mathrm{NaCl}$, $2.0 \mathrm{~g} \mathrm{KCl}, 20 \mathrm{~g} \mathrm{MgSO}_{4} .7 \mathrm{H}_{2} \mathrm{O}, 0.5 \mathrm{~g}$ Casamino acids, $0.5 \mathrm{~g}$ yeast extract, 2.0 g locust-bean gum, 0.3 g sodium citrate, $0.1 \mathrm{~g}$ sodium glutamate, $36 \mathrm{mg} \mathrm{FeCl}_{2} .4 \mathrm{H}_{2} \mathrm{O}, 0.36 \mathrm{mg}$ $\mathrm{MnCl}_{2} \cdot 4 \mathrm{H}_{2} \mathrm{O}$; adjusted to $\mathrm{pH} 7.2$ with $1 \mathrm{M} \mathrm{KOH}$ ]. Solid media contained $20 \mathrm{~g}$ Bacto agar. The medium was based on JCM-168 medium (Japan Collection of Microorganisms, RIKEN BioResource Center). Carbon sources were reduced and locust-bean gum was then added. Salt samples dissolved in sterile water were spread on $168 \mathrm{M}$ medium agar plates and then incubated in plastic bags at $37^{\circ} \mathrm{C}$. After 2-8 weeks of incubation, clear red-coloured colonies developed, and these were transferred to a new plate. The strain was isolated and purified by repeated streaking.

Cells of strain YSM- $123^{\mathrm{T}}$ grown under optimal conditions were Gram-negative, non-motile and extremely pleomorphic (Fig. 1). The cells were typically $1-5 \mu \mathrm{m}$ in diameter in liquid media. On agar medium, the strain formed clear, red microcolonies.

Phenotypic tests were carried out in accordance with the proposed minimum standards for the description of new taxa in the order Halobacteriales (Oren et al., 1997) and included anaerobic growth in the presence of nitrate or

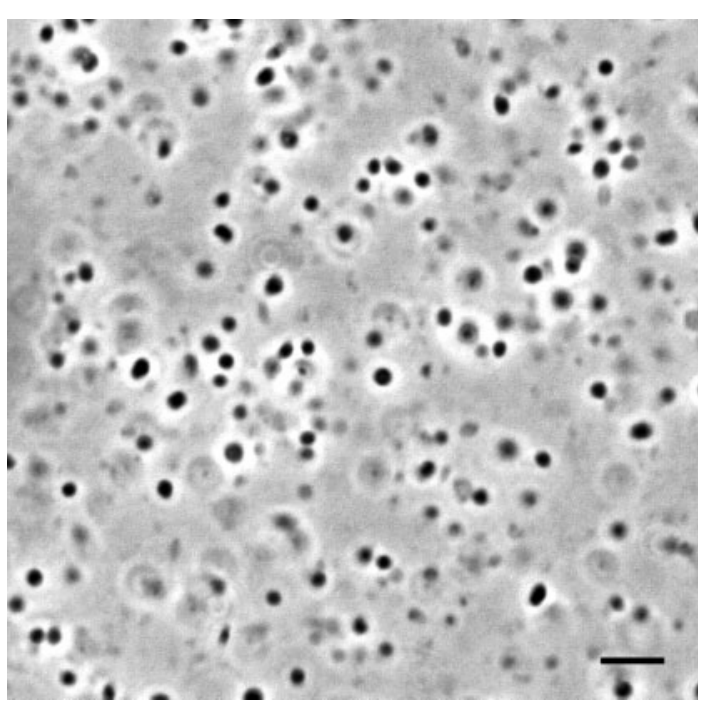

Fig. 1. Phase-contrast micrograph of cells of strain YSM-123'. Bar, $10 \mu \mathrm{m}$. arginine, catalase and oxidase activities and the utilization of sugars, alcohols and organic acids.

Medium A [containing $\left(\mathrm{l}^{-1}\right): 220 \mathrm{~g} \mathrm{NaCl}, 2.0 \mathrm{~g} \mathrm{KCl}, 1.0$ $\mathrm{MgCl}_{2} .6 \mathrm{H}_{2} \mathrm{O}, 1.0 \mathrm{~g} \mathrm{~K}_{2} \mathrm{HPO}_{4}, 0.5 \mathrm{~g}$ Casamino acids, $0.5 \mathrm{~g}$ yeast extract, $0.3 \mathrm{~g}$ sodium citrate, $0.1 \mathrm{~g}$ sodium glutamate, 3.0 g glucose, $18 \mathrm{mg} \mathrm{FeCl} 2.4 \mathrm{H}_{2} \mathrm{O}, 0.18 \mathrm{mg} \mathrm{MnCl}_{2} .4 \mathrm{H}_{2} \mathrm{O}$ ] was used for culture maintenance. The $\mathrm{pH}$ was adjusted to 8.8 with $1 \mathrm{M} \mathrm{KOH}$. Medium B [containing $\left(1^{-1}\right): 220 \mathrm{~g}$ $\mathrm{NaCl}, 2.0 \mathrm{~g} \mathrm{KCl}, 1.0 \mathrm{~g} \mathrm{MgCl}_{2} .6 \mathrm{H}_{2} \mathrm{O}, 1.0 \mathrm{~g} \mathrm{~K}_{2} \mathrm{HPO}_{4}, 0.05 \mathrm{~g}$ yeast extract, $0.5 \mathrm{~g} \mathrm{NH}_{4} \mathrm{Cl}, 18 \mathrm{mg} \mathrm{FeCl}{ }_{2} .4 \mathrm{H}_{2} \mathrm{O}, 0.18 \mathrm{mg}$ $\mathrm{MnCl}_{2} .4 \mathrm{H}_{2} \mathrm{O}, \mathrm{pH} 8.8$; supplemented with $0.5 \%(\mathrm{w} / \mathrm{v})$ carbon source] was used to perform phenotypic tests including utilization of single or complex carbon sources. Antibiotic sensitivity tests were performed by spreading bacterial suspensions on agar of medium A. Discs impregnated with the antibiotics used were applied to the plates.

Detailed results of the physiological and biochemical tests as well as antibiotic susceptibility tests are given in the species description.

Total lipids were extracted by a modified method of Kamekura (1993). Polar lipids were extracted with methanol/chloroform $(2: 1, \mathrm{v} / \mathrm{v})$. Extracts were then dissolved in a small volume of chloroform, applied to silica gel TLC plates and separated by single development with chloroform/ methanol/acetic acid/water $(85: 22.5: 10: 4)$. Lipid spots were detected by spraying with the following reagents: $0.5 \%$ $\alpha$-naphthol in $50 \%$ methanol, followed by $5 \% \mathrm{H}_{2} \mathrm{SO}_{4}$ in ethanol and heating of the plates at $150{ }^{\circ} \mathrm{C}$. Polar lipid analysis showed that the strain contained diether derivatives of phosphatidylglycerol and phosphatidylglycerophosphate methyl ester. Disulfated diglycosyl diether and an unknown glycolipid were also produced (Supplementary Fig. S1, available in IJSEM Online).

The 16S rRNA gene of strain YSM- $123^{\mathrm{T}}$ was amplified by PCR with the forward primer 5'-ATTCCGGTTGATCCTGCCGG-3' and the reverse primer $5^{\prime}$-AGGAGGTGATCCAGCCGCAG-3' using LA-Taq (TaKaRa). PCR was performed for 28 cycles with denaturation for $30 \mathrm{~s}$ at $94{ }^{\circ} \mathrm{C}$, annealing for $45 \mathrm{~s}$ at $55{ }^{\circ} \mathrm{C}$ and polymerization for 2 min at $72{ }^{\circ} \mathrm{C}$. The amplified gene was cloned into pTA2 plasmid vector (TArget clone; TOYOBO) and recombinant plasmids were reproduced in Escherichia coli HB101 (TaKaRa). The sequence of the 16S rRNA gene was determined by the dye-termination method (BigDye cycle sequencing kit version 1.1) using an $\mathrm{ABI} 377$ sequencer. Similarity values were calculated by NCBI BLAST. Phylogenetic analysis and tree construction was performed using the programs CLUSTAL_X (Larkin et al., 2007), RAxML (Stamatakis et al., 2005) and TreeView (Page, 1996).

Phylogenetic analysis based on the 16S rRNA gene sequence suggested that strain YSM-123 ${ }^{\mathrm{T}}$ has two $16 \mathrm{~S}$ rRNA genes, $r r n A$ and $r r n B$, which share $99 \%$ sequence similarity. The NCBI BLAST program indicated that YSM$123^{\mathrm{T}}$ was a member of the phylogenetic group defined by 


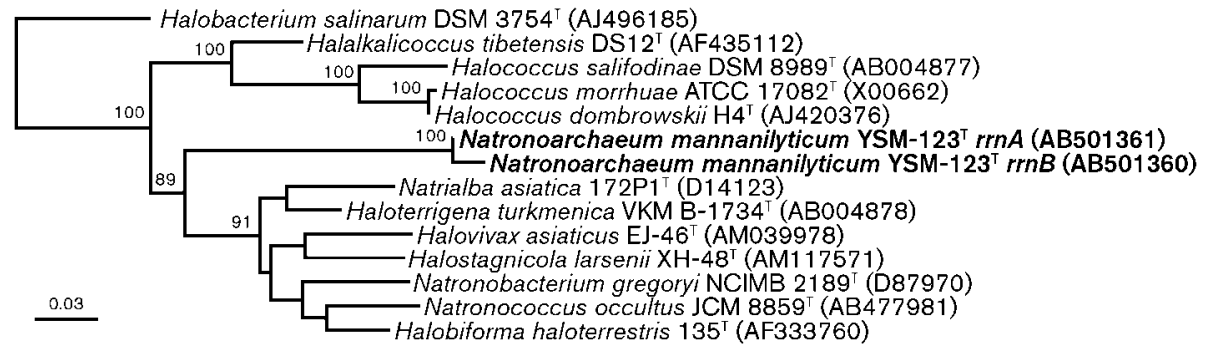

Fig. 2. Maximum-likelihood phylogenetic tree based on $16 \mathrm{~S}$ rRNA gene sequences showing the positions of strain $\mathrm{YSM}^{-123^{\top}}$ and related haloarchaeal strains. GenBank accession numbers are shown in parentheses. Bar, 0.03 changes per nucleotide position. Bootstrap values are percentages of 1000 replicates.

the family Halobacteriaceae, but there were low similarities to type strains of other genera of this family $(\leqslant 90 \%)$; for example, Halococcus (similarity $<89 \%$ ), Halostagnicola $(<89 \%)$, Natronolimnobius $(<89 \%), \quad$ Halobiforma $(<90 \%)$, Haloterrigena $(<90 \%)$, Halovivax $(<90 \%)$, Natrialba $(<90 \%)$, Natronobacterium $(<90 \%)$ and Natronococcus $(<90 \%)$. Tree reconstruction using the maximum-likelihood (Fig. 2) and neighbour-joining (not shown) methods showed similar phylogenetic placement for both genes of YSM-123 ${ }^{\mathrm{T}}$.
The $\mathrm{G}+\mathrm{C}$ content of the DNA was determined by HPLC on a Cosmosil $5 \mathrm{C} 18(150 \times 4 \mathrm{~mm})$ column, according to Tamaoka \& Komagata (1984). The elution buffer was $0.02 \mathrm{M}$ ammonium dihydrogen phosphate/acetonitrile $(40: 1, \mathrm{v} / \mathrm{v})$. The DNA G $+\mathrm{C}$ content was calculated to be $63 \mathrm{~mol} \%$.

The phenotypic and chemotaxonomic data and phylogenetic data based on $16 \mathrm{~S}$ rRNA gene sequence comparison support the placement of strain YSM- $123^{\mathrm{T}}$ in a novel genus

Table 1. Characteristics that distinguish Natronoarchaeum gen. nov. from related haloarchaeal genera

Genera: 1, Natronoarchaeum gen. nov. (strain YSM-123 ${ }^{\mathrm{T}}$ ); 2, Halobiforma; 3, Haloterrigena; 4, Halovivax; 5, Natrialba; 6, Natronobacterium; 7, Natronococcus. Data were derived from Castillo et al. (2006c, 2007), Cui et al. (2006), Gutiérrez et al. (2008), Hezayen et al. (2001), Kanal et al. (1995), Montalvo-Rodríguez et al. (2000), Oren et al. (2009), Roh et al. (2007), Romano et al. (2007), Tapingkae et al. (2008), Xin et al. (2000), Xu et al. (2001, 2005a, b, c) and this study. Members of all genera contain phosphatidylglycerol and phosphatidylglycerophosphate methyl ester. None of the genera contain diglycosyl diether or sulfated tetraglycosyl diether.

\begin{tabular}{|c|c|c|c|c|c|c|c|}
\hline Characteristic & 1 & 2 & 3 & 4 & 5 & 6 & 7 \\
\hline Pigmentation $\dagger$ & $\mathrm{CR}$ & $\mathrm{RD}$ & $\mathrm{RD} / \mathrm{LP}$ & PP & $\mathrm{WH} / \mathrm{RD}$ & $\mathrm{RD}$ & $\mathrm{RD}$ \\
\hline $\mathrm{NaCl}$ optimum $(\mathrm{M})$ & $4.0-4.5$ & 3.4 & $3.0-3.5$ & 3.4 & $3.5-4.0$ & 3.0 & $2.5-3.8$ \\
\hline $\mathrm{pH}$ optimum & $8.0-9.0$ & 7.5 & $7.0-7.5$ & $7.0-7.5$ & $6.6-9.5$ & 9.5 & $9.0-9.5$ \\
\hline $\begin{array}{l}\text { Temperature optimum } \\
\left({ }^{\circ} \mathrm{C}\right)\end{array}$ & 37 & $36-45$ & $40-50$ & 37 & $35-40$ & 37 & $35-45$ \\
\hline $\begin{array}{l}\text { DNA G }+C \text { content } \\
(\mathrm{mol} \%)\end{array}$ & 63 & $64.9-66.9$ & $59.2-66.6$ & $60.3-65$ & $60.3-64.3$ & 65 & $63.5-64$ \\
\hline \multicolumn{8}{|l|}{ Polar lipids $\ddagger$} \\
\hline PGS & - & - & - & - & - & - & + \\
\hline S-DGD & - & - & $-1+$ & - & - & - & - \\
\hline $\mathrm{S}_{2}-\mathrm{DGD}$ & + & - & $-1+$ & - & $-1+$ & - & - \\
\hline
\end{tabular}

${ }^{\star} \mathrm{C}$, Cocci; P, pleomorphic; $\mathrm{R}$, rods.

$\dagger \mathrm{CR}$, Clear red; LP, light pink; PP, pale pink; RD, red; wH, white.

¥PGS, Phosphatidylglycerosulfate; S-DGD, sulfated diglycosyl diether; $\mathrm{S}_{2}$-DGD, disulfated diglycosyl diether; S-TGD, sulfated triglycosyl diether; TGD, triglycosyl diether. 
and species within the haloarchaea. On the basis of these results, particularly the lack of significant $16 \mathrm{~S}$ rRNA gene similarity with representatives of other genera, we propose that strain YSM- $123^{\mathrm{T}}$ should be placed in the new genus and species Natronoarchaeum mannanilyticum gen. nov., sp. nov.

\section{Description of Natronoarchaeum gen. nov.}

Natronoarchaeum [Na.tro' no.ar.chae'um. N.L. n. natron (arbitrarily derived from Arabic n. natrun or natron) soda, sodium carbonate; N.L. pref. natrono- pertaining to soda; N.L. neut. n. archaeum archaeon from Gr. adj. archaios $-\hat{e}-o n$ ancient; N.L. neut. n. Natronoarchaeum the soda archaeon].

Cells are Gram-negative, non-motile and extremely pleomorphic. Colonies on agar are small and are pigmented clear red. Chemo-organotrophic, aerobic, halophilic and slightly alkaliphilic, requiring at least $2 \mathrm{M}$ $\mathrm{NaCl}$ for growth. The major polar lipids are phosphatidylglycerol, phosphatidylglycerophosphate methyl ester and disulfated diglycosyl diether $\left(\mathrm{S}_{2}\right.$-DGD). Phylogenetically, a member of the Halobacteriales. The type species is Natronoarchaeum mannanilyticum. Recommended threeletter abbreviation: Nac.

\section{Description of Natronoarchaeum mannanilyticum sp. nov.}

Natronoarchaeum mannanilyticum (man.na.ni.ly'ti.cum. N.L. neut. n. mannanum mannan; N.L. neut. adj. lyticum from Gr. adj. lytikos able to loosen, able to dissolve; N.L. neut. adj. mannanilyticum mannan-dissolving).

The description is identical to that given for the genus, with the following additions. Cells are typically $1-5 \mu \mathrm{m}$ in diameter in liquid medium. Cells lyse in distilled water. On agar medium, under optimal conditions, forms clear red microcolonies $(0.5-1.0 \mathrm{~mm}$ in diameter after 10 days of growth at $37{ }^{\circ} \mathrm{C}$ ). Grows in 2.0-5.3 (saturated) $\mathrm{M} \mathrm{NaCl}$ (optimum 4.0-4.5 M), at $\mathrm{pH} 5.8-9.5$ (optimum $\mathrm{pH} 8.0$ 9.0) and at $20-55{ }^{\circ} \mathrm{C}$ (optimum $37{ }^{\circ} \mathrm{C}$ ). $\mathrm{Mg}^{2+}$ is required for growth, with maximum growth at $5 \mathrm{mM}$. Phenotypic characteristics are summarized in Table 1 in comparison with other haloarchaea. Catalase- and oxidase-negative. Does not reduce nitrate to nitrite. Anaerobic growth does not occur with nitrate, arginine or DMSO. Indole production from tryptophan is positive. Susceptible to bacitracin, novobiocin and rifampicin and resistant to ampicillin, chloramphenicol, erythromycin, gentamicin, kanamycin, neomycin, penicillin, streptomycin, tetracycline and vancomycin. Utilizes cellobiose, glucose, lactose, mannose, raffinose, locust-bean gum, yeast extract, Casamino acids, peptone, sodium glutamate and pyruvic acid as single or complex carbon sources for growth. Hydrolyses starch. Does not hydrolyse gelatin, Tween 80 or casein. Contains an unknown glycolipid in addition to the polar lipids described for the genus. The DNA G+C content of the type strain is $63 \mathrm{~mol} \%$ as determined by
HPLC. The type strain has two $16 \mathrm{~S}$ rRNA genes that show low sequence similarity $(\leqslant 90 \%)$ to those of other members of the family Halobacteriaceae.

The type strain, YSM $-123^{\mathrm{T}} \quad\left(=\mathrm{JCM} 16328^{\mathrm{T}}=\mathrm{CECT}\right.$ $\left.7565^{\mathrm{T}}\right)$, was isolated from a commercial salt sample made in Niigata prefecture, Japan.

\section{References}

Bardavid, R. E., Mana, L. \& Oren, A. (2007). Haloplanus natans gen. nov., sp. nov., an extremely halophilic, gas-vacuolate archaeon isolated from Dead Sea-Red Sea water mixtures in experimental outdoor ponds. Int J Syst Evol Microbiol 57, 780-783.

Burns, D. G., Janssen, P., Itoh, T., Kamekura, M., Li, Z., Jensen, G., Rodríguez-Valera, F., Bolhuis, H. \& Dyall-Smith, M. (2007). Haloquadratum walsbyi gen. nov., sp. nov., the square haloarchaeon of Walsby, isolated from saltern crystallizers in Australia and Spain. Int J Syst Evol Microbiol 57, 387-392.

Castillo, A. M., Gutiérrez, M., Kamekura, M., Ma, Y., Cowan, D., Jones, B., Grant, W. \& Ventosa, A. (2006a). Halovivax asiaticus gen. nov., sp. nov., a novel extremely halophilic archaeon isolated from Inner Mongolia, China. Int J Syst Evol Microbiol 56, 765-770.

Castillo, A. M., Gutiérrez, M., Kamekura, M., Xue, Y., Ma, Y., Cowan, D., Jones, B., Grant, W. \& Ventosa, A. (2006b). Halostagnicola larsenii gen. nov., sp. nov., an extremely halophilic archaeon from a saline lake in Inner Mongolia, China. Int J Syst Evol Microbiol 56, 1519-1524.

Castillo, A. M., Gutiérrez, M., Kamekura, M., Xue, Y., Ma, Y., Cowan, D., Jones, B., Grant, W. \& Ventosa, A. (2006c). Natrinema ejinorense sp. nov., isolated from a saline lake in Inner Mongolia, China. Int J Syst Evol Microbiol 56, 2683-2687.

Castillo, A. M., Gutiérrez, M., Kamekura, M., Xue, Y., Ma, Y., Cowan, D., Jones, B., Grant, W. \& Ventosa, A. (2007). Halovivax ruber sp. nov., an extremely halophilic archaeon isolated from Lake Xilinhot, Inner Mongolia, China. Int J Syst Evol Microbiol 57, 1024-1027.

Cui, H. L., Tohty, D., Zhou, P. \& Liu, S. (2006). Haloterrigena longa sp. nov. and Haloterrigena limicola sp. nov., extremely halophilic archaea isolated from a salt lake. Int J Syst Evol Microbiol 56, 1837-1840.

Elazari-Volcani, B. (1957). Genus XII. Halobacterium. In Bergey's Manual of Determinative Bacteriology, 7th edn, pp. 207-212. Edited by R. S. Breed, E. G. D. Murray \& N. R. Smith. Baltimore: Williams \& Wilkins.

Grant, W. D., Kamekura, M., McGenity, T. J. \& Ventosa, A. (2001). Order I. Halobacteriales Grant and Larsen, 1989b, $495^{\mathrm{VP}}$ (effective publication: Grant and Larsen, 1989a, 2216). In Bergey's Manual of Systematic Bacteriology, 2nd edn, vol. 1, pp. 294-299. Edited by D. R. Boone, R. D. Castenholz \& G. M. Garrity. New York: Springer.

Gutiérrez, M. C., Castillo, A., Kamekura, M., Xue, Y., Ma, Y., Cowan, D., Jones, B., Grant, W. \& Ventosa, A. (2007). Halopiger xanaduensis gen. nov., sp. nov., an extremely halophilic archaeon isolated from saline Lake Shangmatala in Inner Mongolia, China. Int J Syst Evol Microbiol 57, 1402-1407.

Gutiérrez, M. C., Castillo, A., Kamekura, M. \& Ventosa, A. (2008). Haloterrigena salina sp. nov., an extremely halophilic archaeon isolated from a salt lake. Int J Syst Evol Microbiol 58, 2880-2884.

Hezayen, F. F., Rehm, B., Tindall, B. \& Steinbüchel, A. (2001). Transfer of Natrialba asiatica B1T to Natrialba taiwanensis sp. nov. and description of Natrialba aegyptiaca sp. nov., a novel extremely halophilic, aerobic, non-pigmented member of the Archaea from Egypt that produces extracellular poly(glutamic acid). Int J Syst Evol Microbiol 51, 1133-1142. 
Hezayen, F. F., Tindall, B., Steinbüchel, A. \& Rehm, B. (2002). Characterization of a novel halophilic archaeon, Halobiforma haloterrestris gen. nov., sp. nov., and transfer of Natronobacterium nitratireducens to Halobiforma nitratireducens comb. nov. Int J Syst Evol Microbiol 52, 2271-2280.

Itoh, T., Yamaguchi, T., Zhou, P. \& Takashina, T. (2005). Natronolimnobius baerhuensis gen. nov., sp. nov. and Natronolimnobius innermongolicus sp. nov., novel haloalkaliphilic archaea isolated from soda lakes in Inner Mongolia, China. Extremophiles 9, 111116.

Kamekura, M. (1993). Lipids of extreme halophiles. In The Biology of Halophilic Bacteria, pp. 135-161. Edited by R. H. Vreeland \& L. I. Hochstein. Boca Raton, FL: CRC Press.

Kamekura, M. \& Dyall-Smith, M. L. (1995). Taxonomy of the family Halobacteriaceae and the description of two new genera Halorubrobacterium and Natrialba. J Gen Appl Microbiol 41, 333-350.

Kamekura, M., Dyall-Smith, M., Upasani, V., Ventosa, A. \& Kates, M. (1997). Diversity of alkaliphilic halobacteria: proposals for transfer of Natronobacterium vacuolatum, Natronobacterium magadii, and Natronobacterium pharaonis to Halorubrum, Natrialba, and Natronomonas gen. nov., respectively, as Halorubrum vacuolatum comb. nov., Natrialba magadii comb. nov., and Natronomonas pharaonis comb. nov., respectively. Int J Syst Bacteriol 47, 853-857.

Kanal, H., Kobayashi, T., Aono, R. \& Kudo, T. (1995). Natronococcus amylolyticus sp. nov., a haloalkaliphilic archaeon. Int J Syst Bacteriol 45, 762-766.

Kocur, M. \& Hodgkiss, W. (1973). Taxonomic status of the genus Halococcus Schoop. Int J Syst Bacteriol 23, 151-156.

Larkin, M. A., Blackshields, G., Brown, N. P., Chenna, R., McGettigan, P. A., McWilliam, H., Valentin, F., Wallace, I. M., Wilm, A. \& other authors (2007). CLUSTAL $W$ and CLUSTAL_X version 2.0. Bioinformatics 23, 2947-2948.

McGenity, T. J. \& Grant, W. D. (1995). Transfer of Halobacterium saccharovorum, Halobacterium sodomense, Halobacterium trapanicum NRC 34041 and Halobacterium lacusprofundi to the genus Halorubrum gen. nov., as Halorubrum saccharovorum comb. nov., Halorubrum sodomense comb. nov., Halorubrum trapanicum comb. nov., and Halorubrum lacusprofundi comb. nov. Syst Appl Microbiol 18, 237-243.

McGenity, T. J., Gemmell, R. \& Grant, W. (1998). Proposal of a new halobacterial genus Natrinema gen. nov., with two species Natrinema pellirubrum nom. nov. and Natrinema pallidum nom. nov. Int J Syst Bacteriol 48, 1187-1196.

Montalvo-Rodríguez, R., Vreeland, R., Oren, A., Kessel, M., Betancourt, C. \& López-Garriga, J. (1998). Halogeometricum borinquense gen. nov., sp. nov., a novel halophilic archaeon from Puerto Rico. Int J Syst Bacteriol 48, 1305-1312.

Montalvo-Rodríguez, R., López-Garriga, J., Vreeland, R., Oren, A., Ventosa, A. \& Kamekura, M. (2000). Haloterrigena thermotolerans sp. nov., a halophilic archaeon from Puerto Rico. Int J Syst Evol Microbiol 50, 1065-1071.

Oren, A., Gurevich, P., Gemmell, R. T. \& Teske, A. (1995). Halobaculum gomorrense gen. nov., sp. nov., a novel extremely halophilic archaeon from the Dead Sea. Int J Syst Bacteriol 45, 747754.

Oren, A., Ventosa, A. \& Grant, W. D. (1997). Proposed minimal standards for description of new taxa in the order Halobacteriales. Int J Syst Bacteriol 47, 233-238.

Oren, A., Elevi, R., Watanabe, S., Ihara, K. \& Corcelli, A. (2002). Halomicrobium mukohataei gen. nov., comb. nov., and emended description of Halomicrobium mukohataei. Int J Syst Evol Microbiol 52, 1831-1835.
Oren, A., Arahal, D. \& Ventosa, A. (2009). Emended descriptions of genera of the family Halobacteriaceae. Int J Syst Evol Microbiol 59, 637-642.

Page, R. D. M. (1996). TreeView: an application to display phylogenetic trees on personal computers. Comput Appl Biosci 12, 357-358.

Roh, S. W., Nam, Y., Chang, H., Sung, Y., Kim, K., Lee, H., Oh, H. \& Bae, J. (2007). Natronococcus jeotgali sp. nov., a halophilic archaeon isolated from shrimp jeotgal, a traditional fermented seafood from Korea. Int J Syst Evol Microbiol 57, 2129-2131.

Romano, I., Poli, A., Finore, I., Huertas, F., Gambacorta, A., Pelliccione, S., Nicolaus, G., Lama, L. \& Nicolaus, B. (2007). Haloterrigena hispanica sp. nov., an extremely halophilic archaeon from Fuente de Piedra, southern Spain. Int J Syst Evol Microbiol 57, 1499-1503.

Savage, K. N., Krumholz, L., Oren, A. \& Elshahed, M. (2007). Haladaptatus paucihalophilus gen. nov., sp. nov., a halophilic archaeon isolated from a low-salt, sulfide-rich spring. Int J Syst Evol Microbiol 57, 19-24.

Savage, K. N., Krumholz, L., Oren, A. \& Elshahed, M. (2008). Halosarcina pallida gen. nov., sp. nov., a halophilic archaeon from a low-salt, sulfide-rich spring. Int J Syst Evol Microbiol 58, 856860 .

Stamatakis, A., Ludwig, T. \& Meier, H. (2005). RAxML-III: a fast program for maximum likelihood-based inference of large phylogenetic trees. Bioinformatics 21, 456-463.

Tamaoka, J. \& Komagata, K. (1984). Determination of DNA base composition by reversed-phase high-performance liquid chromatography. FEMS Microbiol Lett 25, 125-128.

Tapingkae, W., Tanasupawat, S., Itoh, T., Parkin, K., Benjakul, S., Visessanguan, W. \& Valyasevi, R. (2008). Natrinema gari sp. nov., a halophilic archaeon isolated from fish sauce in Thailand. Int J Syst Evol Microbiol 58, 2378-2383.

Tindall, B. J., Ross, H. N. M. \& Grant, W. D. (1984). Natronobacterium gen. nov. and Natronococcus gen. nov., two new genera of haloalkaliphilic archaebacteria. Syst Appl Microbiol 5, 41-57.

Torreblanca, M., Rodriguez-Valera, F., Juez, G., Ventosa, A., Kamekura, M. \& Kates, M. (1986). Classification of non-alkaliphilic halobacteria based on numerical taxonomy and polar lipid composition, and description of Haloarcula gen. nov. and Haloferax gen. nov. Syst Appl Microbiol 8, 89-99.

Ventosa, A., Gutiérrez, M., Kamekura, M. \& Dyall-Smith, M. (1999). Proposal to transfer Halococcus turkmenicus, Halobacterium trapanicum JCM 9743 and strain GSL-11 to Haloterrigena turkmenica gen. nov., comb. nov. Int J Syst Bacteriol 49, 131136.

Vreeland, R. H., Straight, S., Krammes, J., Dougherty, K., Rosenzweig, W. \& Kamekura, M. (2002). Halosimplex carlsbadense gen. nov., sp. nov., a unique halophilic archaeon, with three $16 \mathrm{~S}$ rRNA genes, that grows only in defined medium with glycerol and acetate or pyruvate. Extremophiles 6, 445-452.

Wainø, M., Tindall, B. \& Ingvorsen, K. (2000). Halorhabdus utahensis gen. nov., sp. nov., an aerobic, extremely halophilic member of the Archaea from Great Salt Lake, Utah. Int J Syst Evol Microbiol 50, 183190.

Xin, H., Itoh, T., Zhou, P., Suzuki, K., Kamekura, M. \& Nakase, T. (2000). Natrinema versiforme sp. nov., an extremely halophilic archaeon from Aibi salt lake, Xinjiang, China. Int J Syst Evol Microbiol 50, 1297-1303.

Xu, Y., Zhou, P. \& Tian, X. (1999). Characterization of two novel haloalkaliphilic archaea Natronorubrum bangense gen. nov., sp. nov. 
and Natronorubrum tibetense gen. nov., sp. nov. Int J Syst Bacteriol 49, 261-266.

Xu, Y., Wang, Z., Xue, Y., Zhou, P., Ma, Y., Ventosa, A. \& Grant, W. (2001). Natrialba hulunbeirensis sp. nov. and Natrialba chahannaoensis sp. nov., novel haloalkaliphilic archaea from soda lakes in Inner Mongolia Autonomous Region, China. Int J Syst Evol Microbiol 51, 1693-1698.

Xu, X. W., Ren, P., Liu, S., Wu, M. \& Zhou, P. (2005a). Natrinema altunense sp. nov., an extremely halophilic archaeon isolated from a salt lake in Altun Mountain in Xinjiang, China. Int J Syst Evol Microbiol 55, 1311-1314.
Xu, X. W., Wu, M., Zhou, P. \& Liu, S. (2005b). Halobiforma lacisalsi sp. nov., isolated from a salt lake in China. Int J Syst Evol Microbiol 55, 1949-1952.

Xu, X. W., Liu, S., Tohty, D., Oren, A., Wu, M. \& Zhou, P. (2005c). Haloterrigena saccharevitans sp. nov., an extremely halophilic archaeon from Xin-Jiang, China. Int J Syst Evol Microbiol 55, 25392542.

Xue, Y., Fan, H., Ventosa, A., Grant, W., Jones, B., Cowan, D. \& Ma, Y. (2005). Halalkalicoccus tibetensis gen. nov., sp. nov., representing a novel genus of haloalkaliphilic archaea. Int J Syst Evol Microbiol 55, 2501-2505. 